\title{
GERAKAN PEDULI ANAK USIA DINI TIM BERSAMA POSDAYA
}

\author{
Boge Triatmanto ${ }^{1)}$, Eko Yuni Prihantono ${ }^{2)}$, Nawang Warsi ${ }^{3)}$ \\ ${ }^{1)}$ Fakultas Ekonomi \& Bisnis , Universitas Merdeka Malang \\ ${ }^{2)}$ D3 Keuangan dan Perbankan, Universitas Merdeka Malang \\ ${ }^{3)}$ Fakultas Psikologi Universitas Merdeka Malang
}

\begin{abstract}
Abstrak
Pendidikan merupakan aset penting bagi kemajuan sebuah bangsa, oleh karena itu setiap warga Negara harus dan wajib mengikuti jenjang pendidikan, baik jenjang pendidikan anak usia dini, pendidikan dasar, pendidikan menengah maupun tinggi. Dalam bidang pendidikan pelayanan yang tepat, pemahaman mengenai karakteristik anak sesuai pertumbuhan dan perkembangannya akan sangat membantu dalam menyesuaikan proses belajar bagi anak dengan usia, kebutuhan, dan kondisi masing-masing, baik secara intelektual, emosional dan sosial.

Pada saat usia antara 0-6 tahun, otak berkembang sangat cepat hingga 80 persen. Pada usia tersebut otak menerima dan menyerap berbagai macam informasi, tidak melihat baik dan buruk. Itulah masa-masa yang dimana perkembangan fisik, mental maupun spiritual anak akan mulai terbentuk. Karena itu, banyak yang menyebut masa tersebut sebagai masa-masa emas anak (Golden Age). oleh karena itu, kita sebagai orangtua hendaknya memanfaatkan masa emas anak untuk memberikan pendidikan karakter yang baik bagi anak. Sehingga anak bisa meraih keberhasilan dan kesuksesan dalam kehidupannya di masa mendatang.

Untuk menunjang perkembangan anak usia dini tim bekerjasama dengan posdaya binaan LPPM Unmer Malang melakukan pengabdian untuk mencerdaskan anak usia dini serta membekali para pengelola Pendidikan Anak Usia Dini dalam menghadapi berbagai permasalahan dalam mendidik anak usia dini dengan mengadakan seminar, serta beberapa kegiatan penunjang pembelajaran bagi anak usia dini dengan memberikan penyuluhan, lomba, serta pemberian tambahan gizi bagi anak usia dini
\end{abstract}

Kata kunci : Anak Usia Dini, Golden Age, Posdaya

\section{PENDAHULUAN}

\section{Posdaya}

Lima pilar pemberdayaan keluarga adalah 1) Pendidikan, 2) kesehatan, 3) Lingkungan, 4) Ekonomi dan 5) Agama dan Budaya. Sebagai mitra binaan LPPM, Posdaya telah melakukan pemberdayaan kepada masyarakat sekitar dengan ikut aktif dalam mengelola PAUD Pemberdayaan secara substansial merupakan proses memutus atau break down hubungan antara subyek dan obyek. Proses ini mementingkan pengakuan subyek akan kemampuan atau daya (power) yang dimiliki obyek. Pemberdayaan masyarakat menjadi suatu agenda penting yang harus dilakukan secara menyeluruh.Namun hingga saat ini pada tingkat regional, kegiatan pemberdayaan belum mencapai sasaran dan menghasilkan out put yang diharapkan, karena tingkat kemiskinan masih relatif tinggi.

Salah satu program pemberdayaan masyarakat yang dilakukan Universitas Merdeka Malang adalah program POSDAYA (Pos Pemberdayaan Keluarga). Posdaya merupakan forum silaturahmi, komunikasi, dan wadah kegiatan penguatan fungsi keluarga secara terpadu. Yang kegiatannya menitikberatkan pada 5 pilar pemberdayaan yakni bidang ekonomi produktif, bidang pendidikan, bidang kesehatan, bidang lingkungan dan bidang sosial budaya.Penguatan pilar-pilar utama tersebut diharapkan dapat memberi penguatan bagi keluarga untuk menjadi keluarga mandiri dan sejahtera sehingga mampu menghadapi tantangan kehidupan. Yang pada intinya dengan pemberdayaan ini masyarakat bisa memenuhi kebutuhan ekonomi, kesehatan prima, pendidikan layak, lingkungan sehat, dan memiliki kehidupan beragama serta berkehidupan sosial yang semakin membaik. Pemberdayaan masyarakat yang dilakukan oleh tim dengan menggandeng Posdaya yang ada diwilayah Malang Raya.

\section{Pentingnya Pendidikan Anak Usia Dini}

Yang dimaksud dengan anak usia dini adalah anak dalam rentangan 0-6 tahun menurut Pasal $28 \mathrm{UU}$ Sisdiknas No.20/2013 ayat 1. Sementara menurut kajian rumpun keilmuan PAUD dan penyelenggaraannya di beberapa negara, PAUD dilaksanakan sejak usia 0-8 tahun (masa emas). Pendidikan anak usia dini (PAUD) adalah jenjang pendidikan sebelum jenjang pendidikan dasar yang merupakan suatu upaya pembinaan yang ditujukan 
bagi anak sejak lahir sampai dengan usia enam tahun yang dilakukan melalui pemberian rangsangan pendidikan untuk membantu pertumbuhan dan perkembangan jasmani dan rohani agar anak memiliki kesiapan dalam memasuki pendidikan lebih lanjut, yang diselenggarakan pada jalur formal, nonformal, dan informal. Sementara ruang Lingkup Pendidikan Anak Usia Dini :

- Infant (0-1 tahun)

- Toddler (2-3 tahun)

- Preschool/ Kindergarten children (3-6 tahun)

- Early Primary School (SD Kelas Awal) (6-8 tahun)

Pendidikan anak usia dini merupakan salah satu bentuk penyelenggaraan pendidikan yang menitikberatkan pada peletakan dasar ke arah pertumbuhan dan 5 perkembangan, yaitu : perkembangan moral dan agama, perkembangan fisik (koordinasi motorik halus dan kasar), kecerdasan/kognitif (daya pikir, daya cipta), sosio emosional (sikap dan emosi) bahasa dan komunikasi, sesuai dengan keunikan dan tahap-tahap perkembangan sesuai kelompok usia yang dilalui oleh anak usia dini seperti yang tercantum dalam Permendiknas no 58 tahun 2009.

Ada dua tujuan diselenggarakannya pendidikan anak usia dini yaitu:

- Tujuan utama: untuk membentuk anak Indonesia yang berkualitas, yaitu anak yang tumbuh dan berkembang sesuai dengan tingkat perkembangannya sehingga memiliki kesiapan yang optimal di dalam memasuki pendidikan dasar serta mengarungi kehidupan pada masa dewasa.

- Tujuan penyerta: untuk membantu menyiapkan anak mencapai kesiapan belajar (akademik) di sekolah, sehingga dapat mengurangi usia putus sekolah dan mampu bersaing secara sehat di jenjang pendidikan berikutnya.

\section{METODE KEGIATAN}

\section{a. Seminar Strategi Pembelajaran Bagi pamong PAUD}

Anak usia dini merupakan usia emas bagi pertumbuhan karakter dan kecerdasannya, untuk itu perlu dilakukan kegiatan yang bisa menjadi pendukung pembentukan karakter dan kecerdasan mereka. Salah satu cara yang bisa dilakukan adalah dengan memberikan bekal pengetahuan bagi pendidik/guru PAUD untuk bisa mengelola anak didiknya sesuai dengan usia dan karakter anak. Sebagai bentuk kepedulian Unmer bersama dengan
Yayasan Damandiri melalui Program POSDAYA telah melakukan kegiatan Seminar Strategi Pembelajaran Bagi Pamong/Guru PAUD, Seminar dilaksanakan pada tanggal 25 Juli 2013 mulai pukul 08.00 - 14.00 di Hall Alamanda Kusuma Agro Wisata Batu, dengan jumlah peserta 86 orang yang terdiri dari para Guru PAUD Kota Batu.

Pembicara:

a) Nawang Warsi Wulandari S.Psi, M.Psi dengan topik Mengelola Anak Usia Dini. Anak usia dini menurut UU RI No 20 tahun 2013 Psl 1ayat 14 adalah anak yang memiliki usia antara $0-6$ tahun. Dalam usia itu anak memiliki karakteristik : 1) bersifat ego sentries, 2) memiliki rasa ingin tahu yang besar, 3) anak adalah makhluk social, 4) anak bersifat unik, 5) Kaya dengan fantasi, 6) rentan daya konsentrasi pendek, 7) Masa paling potensial untuk belajar, 8) peniru ulung.

Dalam perkembangan social emosionalnya pola perilaku social yang tampak: kerjasama, persaingan, kemurahan hati, hasrat akan penerimaan social, simpati, empati, ketergantungan, sikap ramah, sikap tidak mementingkan diri sendiri, meniru, perilaku kelekatan. Seiring dengan perkembangan usianya mulai terlihat perkembangan emosinya, dimana perkembangan emosi berawal dari kepercayaan dan kenyamanan terhadap diri dan lingkungan, perlu pengkondisian dari lingkungan dengan tepat, serta perlu metode yang pas untuk keunikan masing-masing anak.

b) DR Ach. Rasyad, M.Pd dengan topik Metode Pembelajaran Anak Usia Dini

Anak usia dini belum memahami urutan waktu secara baik, karena focus mereka adalah hari ini dan sekarang. Namun mereka dapat mempelajarinya melalui jadwal harian mereka, apa yang telah mereka lakukan kemarin, hari ini dan besok. Tujuan dari pembelajaran bagi anak usia dini adalah munculnya anak-anak yang mandiri yakni anak yang dapat menyelesaikan persoalannya sendiri, bertanggungjawab, siap melanjutkan pendidikan kejenjang berikutnya, siap menghadapi masa depan.

Dunia anak adalah dunia bermain, bermain adalah medium dimana si anak mencoba diri, bukan saja dalam fantasinya tetapi juga benar nyata secara aktif. Bila anak bermain secara bebas, sesuai kemauan, kecepatannya sendiri, maka ia melatihkemampuannya. Model pembelajaran dalam PAUD : 1) Model Montessori (pembelajaran anak yang mengalami kebutuhan khusus), 2) Model Bank Street 
(pembelajaran anak melalui interaksi dengan benda dan lingkungannya), 3) Model High Scope (anak sebagai pembelajar aktif yang menggunakan sebagian besar waktunya di dalam learning center yang beragam), 4) model pembelajaran suara, bentuk dan bilangan (model pembelajaran dengan metode pengembangan bahasa, pengetahuan sejarah, pengetahuan bumi, pengetahuan tentang bangun, menggambar dan menulis serta pengetahuan yang berkaitan dengan berhitung), 5) Model pembelajaran Child Observation Record ( Model pembelajaran dengan mengobservasi inisiatif, hubungan social, representasi kreatif, music dan gerakan, bahasa dan literaur), 6) Model Beyond Centers and Circle Time (Pembelajaran yang berpusat pada anak, dengan menempatkan setting lingkungan main sebagai pijakan awal yang penting, kegiatan anak terpusat disentra main yang berfungsi sebagai pusat minat, dan guru sebagai fasilitator, motivator dan evaluator), 7) Model Montessori (metode pembelajaran dengan langkah menunjukkan, mengenal dan mengingatkan)

\section{KELOLA ANAK SESUAI DENGAN KARAKTER DAN KEKHASAN MEREKA, ANAK BUKAN MINIATUR ORANG DEWASA , BIARKAN MEREKA TUMBUH DAN
BERKEMBANG SESUAI POTENSI DIRI MEREKA.}

Sasaran kegiatan adalah para guru PAUD, dimana tujuannya adalah agar para guru PAUD memahami proses pembelajaran yang sesuai dengan potensi anak didik mereka. Dari hasil seminar banyak sekali kasus yang terungkap dan bisa dipetik hikmahnya: anak kecil bukan sekedar anak, anak harus dipahami, anak mengerti apa yang dilihat, anak kecenderungan meniru perilaku orang dewasa, sehingga dari sini orang tua sebagai guru dilingkungan keluarga harus selalu bertindak hati-hati agar tidak ditiru anak, orang tua harus selalu terbuka dengan guru pengasuh anak disekolah agar permasalahan yang terjadi pada si anak bisa diselesaikan.

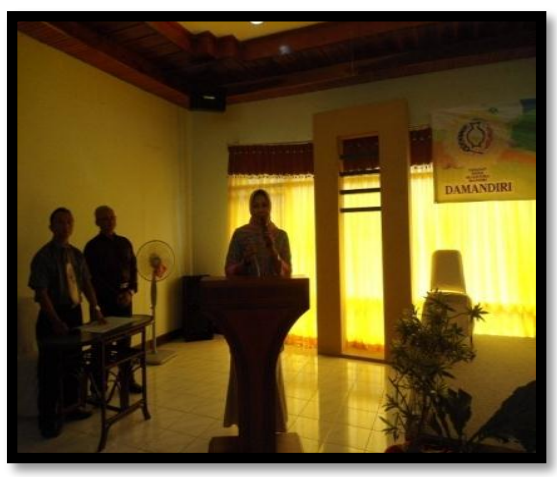

Gambar 1. Pembukaan dan Sambutan Ibu Walikota Batu

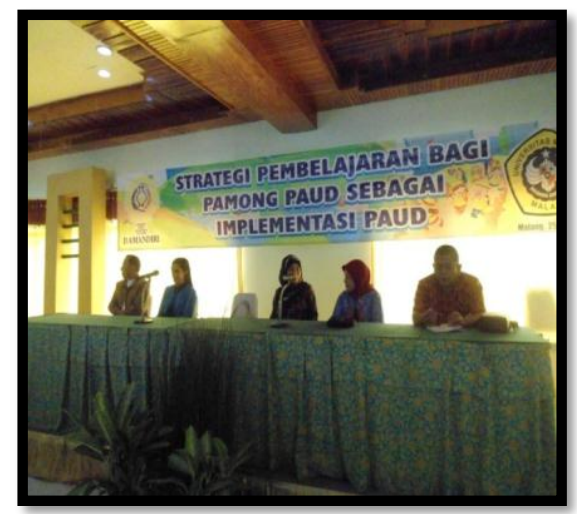

Gambar 2. Penyampaian materi oleh ibu Nawang Warsi

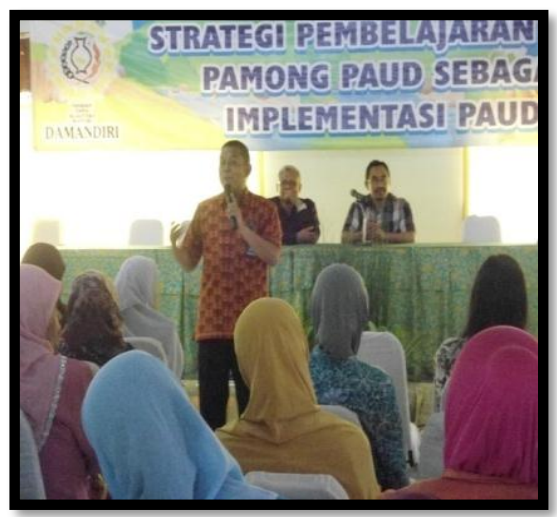

Gambar 3. Penyampaian materi oleh pak Arsyad

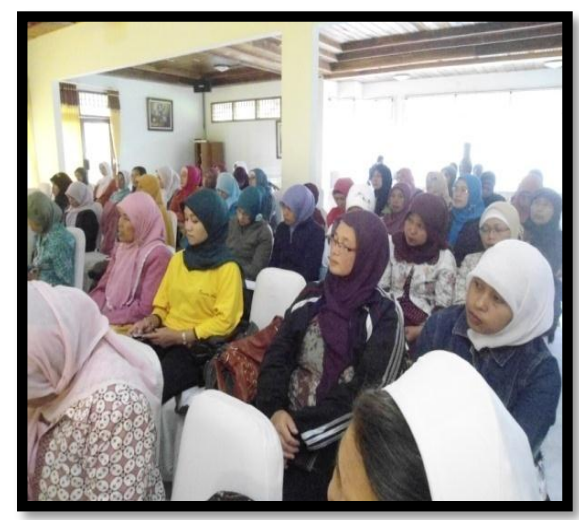

Gambar 4. Peserta seminar ibu ibu guru PAUD 


\section{b. Festival PAUD}

Pendidikan Anak Usia Dini sebagai wadah mengembangkan potensi anak usia dibawah 6 tahun (pra sekolah) untuk siap melanjutkan pendidikan yang lebih tinggi. Sebagai bekal anak-anak diberi pelatihan seni tari untuk mengasah ketrampilan dan kepekaan mereka terhadap budaya. Pada tanggal 12 oktober mulai pukul 08.00 sampai dengan 14.00 LPPM Unmer Malang mengadakan lomba tari bagi siswa PAUD. Lomba ini diikuti 14 PAUD dengan jumlah siswa setiap PAUD 5 orang, yang dipandu 2 orang guru dan diserta dengan 5 orang tua wali mereka.

Kegiatan ini mendapat apresiasi dari para orang tua/wali murid PAUD, hal ini bisa dilihat dari antusiasme orang tua yang mengikuti/mengantar anaknya untuk lomba tari. Dari 14 PAUD yang mengikuti lomba tari, sebagai juara pertama adalah Pos PAUD Ade Irma suryani Kel Rampal Celaket (dengan nomor peserta 12), Juara kedua Pos PAUD Tunas bangsa Kel Sukun (dengan nomor peserta 2), dan Juara 3 Pos PAUD Melati Kel Klojen (dengan nomor peserta 5)

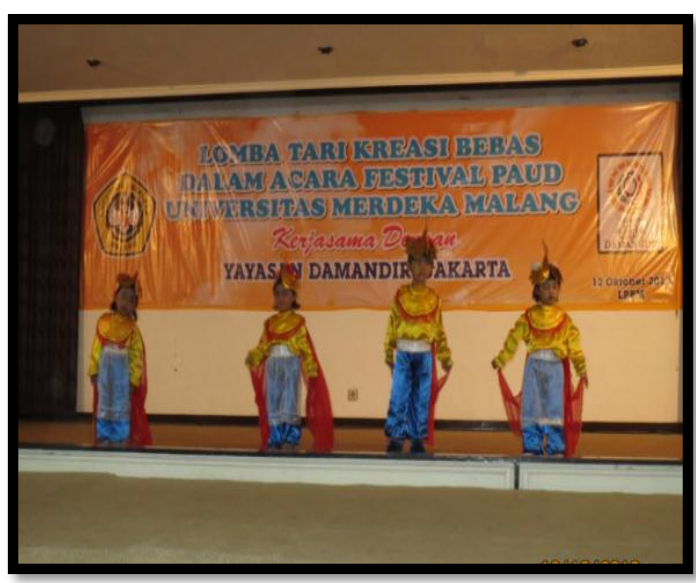

Gambar 5. Peserta lomba Tari Kupu-Kupu

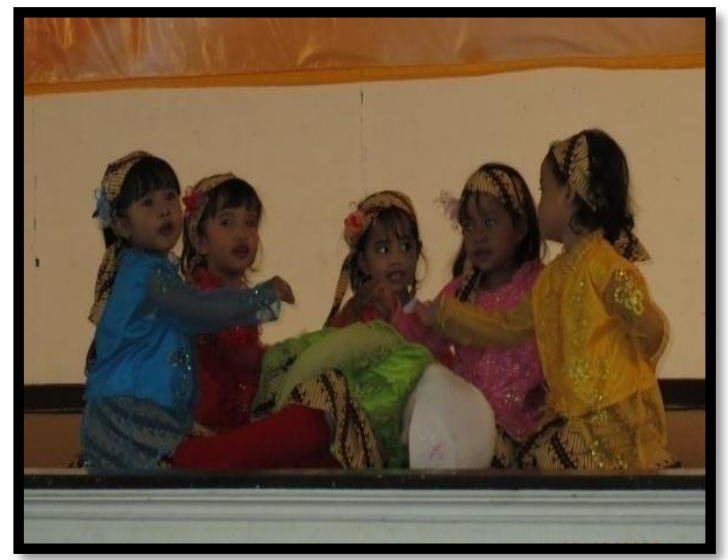

Gambar 6. Peserta lomba tari cublak-cublak suweng

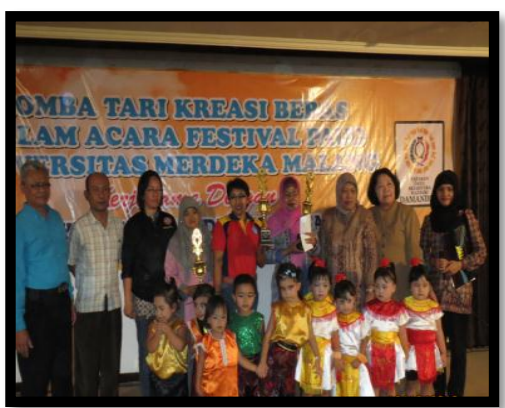

Gambar 7. Pemenang lomba dalam vestival PAUD

\section{c. Pemberian Tambahan Gizi Anak Usia Dini}

Sehat, bahagia dan sejahtera merupakan idaman setiap keluarga. Dengan kondisi ini kemakmuran keluarga akan tercapai, tim bersama posdaya memberikan sumbangan makanan bergizi untuk meningkatkan kesehatan bagi keluarga, dimana sasaran program adalah kesehatan anak. Adanya program ini mendapat sambutan baik dari para kader kesehatan karena dengan pemberian dana ini maka akan menambah asupan gizi bagi warga yang kurang mampu. Untuk tambahan gizi bagi balita ini dikelola oleh posyandu dibantu tim dan beberapa mahasiswa sebagai relawan, Tambahan gizi yang dilakukan dengan memberikan kacang hijau, sayur sup dan sebagian susu balita.

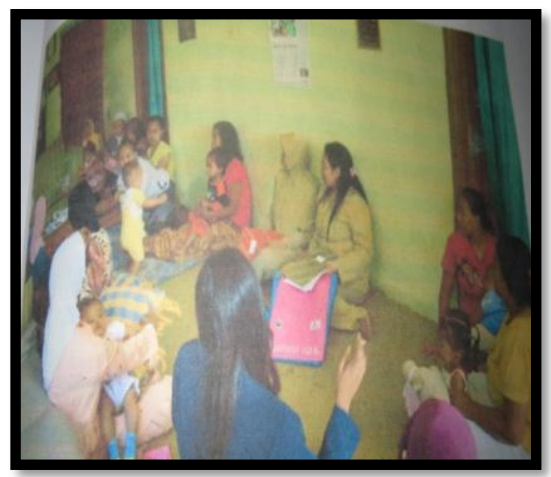

Gambar 8. Penjelasan tim kepada ibu pengelola posyandu

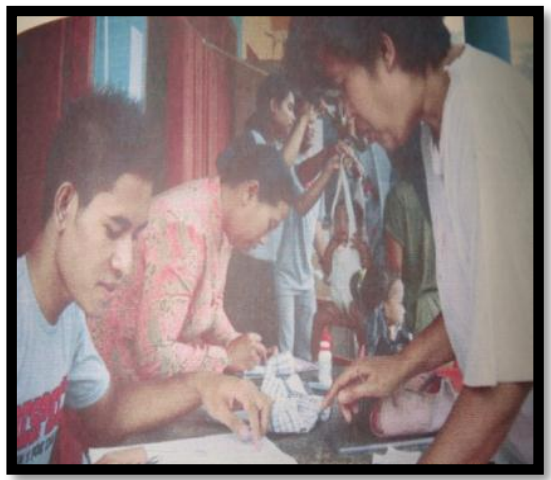

Gambar 9. Pemberian tambahan Gizi Anak Usia Dini 


\section{d. Penyuluhan Hidup bersih dan sehat serta cinta lingkungan}

Salah satu kegiatan penyuluhan kesehatan yang dilakukan tim bersama mahasiswa adalah memberikan penyuluhan kebersihan diri dan kebersihan gigi bagi murid SD kelas stu dan kelas dua. Dengan penyuluhan ini murid SD yang semula tidak peduli untuk selalu membersihkan tangan mereka ketika mau makan, dan malas untuk menyikat gigi, setelah acara ini mereka rajin membersihkan tangan mereka dan menyikat gigi dengan baik dan benar sehingga kesehatan mereka terjaga.

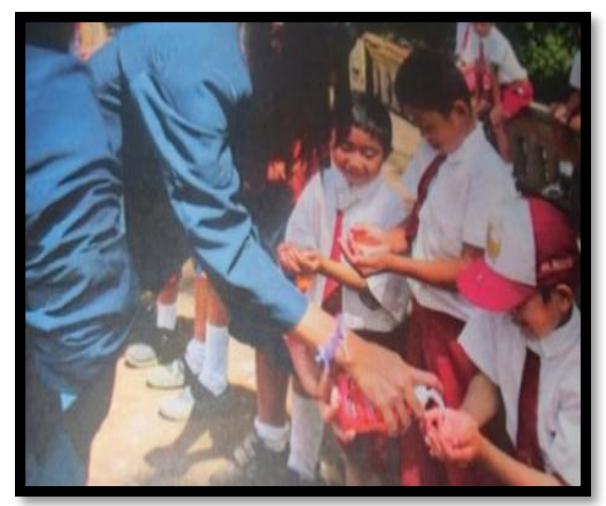

Gambar 10. Praktek cuci tangan siswa kelas 1-2

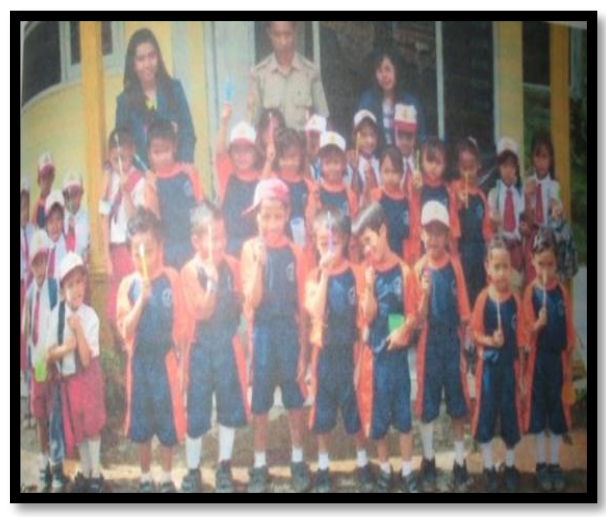

Gambar 11. Praktek sikat Gigi kelas 1-2

\section{Lomba mewarna taman kanak-kanak}

Anak-anak merupakan asset Negara, sehingga perlu untuk mendapat pemberdayaan juga, cara mudah memberdayakan anak-anak adalah memberikan kegiatan sesuai dengan kemampuan fisik dan kecerdasan mereka, salah satu cara memberdayakan anak-anak adalah dengan mengikutkan mereka dalam kegiatan lomba mewarna. Dengan adanya lomba ini akan merangsang mereka untuk kreatif dan bersaing sehat.

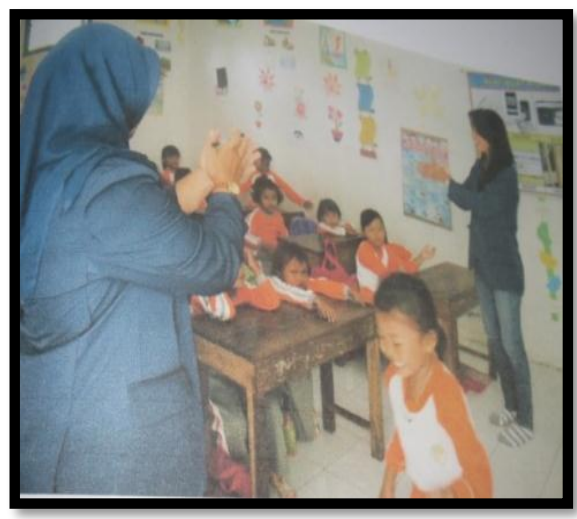

Gambar 12. penjelasan tentang lomba

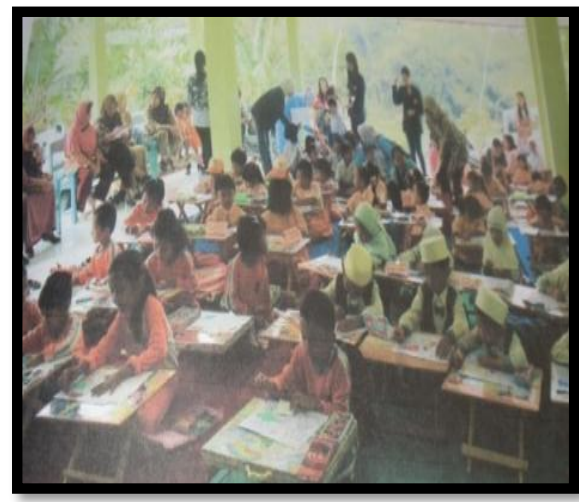

Gambar. 13. Pelaksanaan lomba mewarna

\section{HASIL DAN PEMBAHASAN}

\section{Strategi Pembelajaran Anak Usia Dini}

Strategi pembelajaran sebagai segala usaha guru dalam menerapkan berbagai metode pembelajaran untuk mencapai tujuan yang diharapkan Ada bermacam-macam strategi pembelajaran yang dapat dipilih oleh guru Pendidikan anak usia dini. Pemilihan strategi pembelajaran hendaknya mempertimbangkan beberapa faktor penting, yaitu: a. karakteristik tujuan pembelajaran, b. karakteristik anak dan cara belajarnya, c. tempat berlangsungnya kegiatan belajar, d. tema pembelajaran, serta e. pola kegiatan

Jenis-jenis Strategi Pembelajaran untuk anak usia dini:

\section{a. Strategi Pembelajaran yang Berpusat pada Anak}

Pendekatan yang melandasi pembelajaran yang berpusat pada anak

Anak merupakan individu yang sedang tumbuh dan berkembang. Anak juga merupakan makhluk yang aktif. Atas dasar fakta tersebut maka dikembangkan strategi pembelajaran berdasarkan: 1) pendekatan perkembangan dan 2) pendekatan belajar aktif. 


\section{b. Strategi Pembelajaran Melalui Bermain}

Bermain merupakan kebutuhan anak. Bermain merupakan aktivitas yang menyatu dengan dunia anak, yang di dalamnya terkandung bermacammacam fungsi seperti pengembangan kemampuan fisik motorik, kognitif, afektif, social, dst. Dengan bermain akan mengalami suatu proses yang menarahkan pada perkembangan kemampuan manusiawinya.

\section{c. Strategi Pembelajaran Melalui bercerita}

Pencapaian tujuan pendidikan Taman Kanakkanak dapat ditempuh dengan strategi pembelajaran melalui bercerita. manfaat cerita bagi anak TK, yaitu sebagai berikut: 1. Bagi anak TK mendengarkan cerita yang menarik dan dekat dengan lingkungannya merupakan kegiatan yang mengasyikkan. 2. Guru dapat memanfaatkan kegiatan bercerita untuk menanamkan nilai-nilai positif pada anak. 3 . Kegiatan bercerita juga memberikan sejumlah pengetahuan social, nilai-nilai moral dan keagamaan. 4. Pembelajaran dengan bercerita memberikan memberikan pengalaman belajar untuk mendengarkan. 5. Dengan dengan mendengarkan cerita anak dimungkinkan untk mengembangkan kemampuan kognitif, afektif, dan psikomotorik. 6 . Membantu anak untuk membangun bermacammacam peran yang mungkin dipilih anak, dan bermacam layanan jasa yang ingin disumbangkan anak kepada masyarakat.

\section{d. Strategi Pembelajaran Melalui Bernyanyi}

Bernyanyi memiliki banyak manfaat untuk praktik pendidikan anak dan pengembangan pribadinya secara luas karena : 1) bernyanyi bersifat menyenangkan, 2) bernyanyi dapat dipakai untuk mengatasi kecemasan, 3) bernyanyi merupakan media untuk mengekspresikan perasaan, 4) bernyanyi dapat membantu membangun rasa percaya diri anak, 5) bernyanyi dapat membantu daya ingat anak, 6) bernyanyi dapat mengembangkan rasa humor, 7) bernyanyi dapat membantu pengembangan keterampilan berpikir dan kemampuan motorik anak, dan 8) bernyanyi dapat meningkatkan keeratan dalam sebuah kelompok.

\section{Strategi Pembelajaran Terpadu}

Anak adalah makhluk seutuhnya, yang memiliki berbagai aspek kemampuan, yang semuanya perlu dikembangkan. Berbagai kemampuan yang dimiliki oleh anak dapat berkembang jika ada stimulasi untuk hal tersebut. Dengan pembelajaran terpadu, pembelajaran yang mengintegrasikan ke dalam semua bidang kurikulum atau bidang-bidang pengembangan, berbagai kemampuan anak yang ada pada anak diharapkan dapat berkembangan secara optimal.

Strategi pembelajaran terpadu direncanakan dan dilaksanakan berdasarkan prinsip-prinsip: 1) berorientasi pada perkembangan anak, 2) berkaitan dengan pengalaman nyata anak, 3) mengintegrasikan isi dan proses belajar, 4) melibatkan penemuan aktif, 5) memadukan berbagai bidang pengembangan, 6) kegiatan belajar bervariasi, 7) memiliki potensi untuk dilaksanakan melalui proyek oleh anak, 8) waktu pelaksanaan fleksibel, 9) melibatkan anggota keluarga anak, 10) tema dapat diperluas, dan 11) direvisi sesuai dengan minat dan pemahaman yang ditunjukkan anak (Masitoh dkk., 2005: 12.10).

Ada beberapa manfaat dari strategi pembelajaran terpadu, yaitu: 1) meningkatkan perkembangan konsep anak, 2) memungkinkan anak untuk mengeksplorasi pengetahuan melalui berbagai kegiatan, 3) membantu guru dan praktisi lainnya untuk mengembangkan kemampuan profesionalnya, dan 4) dapat dilaksanakan pada jenjang program yang berbeda, utnuk semua tingkat usia, dan untuk anakanak berkebutuhan khusus.

\section{Perilaku Hidup Bersih dan Sehat}

Anak adalah generasi masa depan suatu bangsa. Pembentukan generasi masa depan bangsa yang kuat, cerdas, kreatif, dan produktif, merupakan tanggungjawab semua pihak. Tumbuh kembang anak secara optimal dalam semua aspek (jasmani, mental,pemikiran) berarti harus mendapatkan perhatian semua pihak. Kebijakan pemerintah ikut mensukseskan terwujudnya suatu generasi bangsa yang kuat, cerdas, kreatif, dan produktif. Tanda anak sehat menurut Depkes (2009) memiliki kriteria : berat badan naik sesuai garis pertumbuhan mengikuti pita hijau pada Kartu Menuju Sehat (KMS), atau naik ke pita warna di atasnya, anak bertambah tinggi, kemampuan bertambah sesuai usia, jarang sakit, ceria, aktif,dan lincah. Pembentukan kesehatan anak tidak berjalan secara tiba-tiba atau instan, melainkan berproses sejak masa kehamilan sang ibu. Banyak faktor yang mempengaruhi kesehatan anak, antara lain pemberian asi saat bayi,imunisasi, status gizi, dan penyakit infeksi pada anak. Faktor-faktor tersebut berkaitan erat dengan perilaku sehat anak itu sendiri dan perilaku sehat orang-orang terdekat disekitar anak

Anak yang mendapatkan pendidikan dan pembinaan sejak dini tentang kesehatan, diharapkanakan dapat memiliki kebiasaan sehat, pengetahuan tentang kesehatan dan dapat 
bertanggungjawabuntuk berperilaku sehat ketika anak tersebut beranjak dewasa. Perilaku kesehatan saat dewasaberhubungan dengan pendidikan kesehatan yang diterima oleh seseorang ketika masa kecil. Perilaku hidup bersih dan sehat (PBHS) bertujuan membentuk perilaku yang bersifat preventive terhadap penyakit.

\section{Pendidikan Seni Bagi Anak Usia Dini}

Masa anak-anak adalah masa dimana perkembangan otak berjalan sangat efektif. Pada masa ini anak akan dikenalkan pada banyak hal yang akhirnya menimbulkan rasa ingin tahu yang kadang berlebihan. Di masa ini pula bakat serta potensi akademis dan non akademis dari anak bermunculan dan sangat potensial untuk disalurkan ke berbagai bidang pendidikan, salah satunya pendidikan seni usia dini.

Rasa percaya diri pada anak usia dini, akan berdampak langsung pada pertumbuhannya. Hal tersebut merupakan bentuk dasar dari bagaimana seorang anak mengenal akan dirinya dan nilai atau hal penting akan dirinya. Karena pada usia remaja, seorang anak mulai mendapatkan rasa sebagai individu, maka periode anak usia dini adalah masa yang mendukung pengembangan percaya diri yang sehat. Anak-anak kecil biasanya menikmati kegiatan seni dan mendapatkan kepuasan dari partisipasnya dalam berbagai hal. Membuat sesuatu atas diri mereka sendiri dan merasa bangga akan penciptaannya, dapat mendukung pembentukan rasa percaya diriyang baik. Anak-anak juga belajar mengenai pujian atau kritik oleh guru, orang tua dan anak-anak lain mengenai karya yang telah dibuatnya.

Pendidikan seni bisa beragam bentuknya, seperti seni musik, seni rupa, seni tari, drama, dsb. Masingmasing dari seni tersebut mengajarkan ketrampilan yang berbeda sesuai bakat anak. Namun tujuannya tetaplah sama yaitu merangsang saraf motorik anak untuk berkreasi tanpa batas, membentuk pola pikir kreatif, serta memberikan keterampilan seni yang sangat berperan dalam kehidupannya.

Pengembangan keterampilan seni bisa dilakukan dengan banyak cara, seperti pendidikan seni dalam organisasi formal atau informal, penanaman nilainilai seni oleh para orang tua atau bakat spontan yang terkadang membuat pendidikan seni menjadi lebih mudah diserap. Pendidikan seni usia dini dikemas lebih menarik dan sesuai dengan pola pikir anak seusianya. Pemberian materinya lebih santai dan tidak menuntut aak untuk selalu menghasilkan karya yang baik. Pengajar seni hanya bertugas untuk mengomentari dan memberikan masukan yang konstruktif demi meningkatkan kemampuan seninya.
Pemberian masukan juga harus menggunakan bahasa yang mudah diterima oleh otak anak seusianya.

Dalam pemberian materi seni, anak harus dibuat sebisa mungkin merasa nyaman dan membentuk pola pikir anak bahwa seni itu indah, menyenangkan dan bermanfaat bagi dirinya kelak. Pandangan anak usia dini terhadap seni masih semu dan sangat sederhana. Oleh karena itu, pengajar seni harus mampu mengkomplekskan pola pikirnya tentang seni yang beragam. Seni bukan lagi menjadi pengembangan diri sampingan tetapi sudah menjadi pendidikan fundamental pendukung kesuksesan seseorang, karena dalam kehidupan bermasyarakat keterampilan selalu diperhatikan.

\section{KESIMPULAN}

\subsection{Kesimpulan}

Usia dini merupakan usia yang sangat rentan terhadap kesalahan pendidikan, jika pendidikan yang diberikan salah maka setelah dewasa mereka akan berperilaku tidak baik, oleh karena itu maka pendidikan anak usia dini harus dipoles dengan benar sehingga nantinya ketika dewasa menjadi anak yang benar benar dapat mandiri, bermanfaat bagi lingkungan sekitar. Untuk memberikan aura positif dalam kehidupan anak usia dini diperlukan strategi pembelajaran yang lebih mudah dipahami dan dijalankan oleh mereka. Kecenderungan usia dini dapat menerima pembelajaran dengan permainan, lagu atau dengan gambar sehingga dalam mendidik mereka harus disertai alat peraga.

\subsection{Saran}

Sebagai orang/lembaga yang peduli terhadap perkembangan anak usia dini sudah selayaknya lah jika kita atau lembaga kita senantiasa menjalin kerjasama dengan berbagai institusi pengelola anak usia dini dengan memberikan berbagai pelatihan atau memberikan bantuan faslitas pembelajaran bagi pendidikan anak usia dni, karena dengan bantuan kita keberlanjutan pendidikan anak usia dini bisa terjamin dan selanjutnya kemampuan anak usia dini juga akan mengalami peningkatan. Sehingga generasi mendatang yang tercetak adalah generasi prima yang smart.

\section{REFERENSI}

Chasa Rika, 2012, Pentingnya Pendidikan Seni pada Anak Usia Dini http://rikachasha.blogspot.co.id

Mardhiati Adiwiryono Retno, 2017, Pesan kesehatan: Perilaku Hidup Bersih dan Sehat (PHBS) Anak Usia Dini Dalam Kurikulum Pendidikan Anak Usia Dini, http://www.foxitsoftware.com

http://www. pendidikankarakter.com/membangunkarakter-sejak-pendidikan-anak-usia-dini/ 